\title{
IKONOMIKA
}

JurnalEkonomidanBisnis Islam (Journal of Islamic Economics and Business)

Volume I, Nomor2, Oktober 2016

ISSN: 2527-3434 (PRINT)- ISSN: 2527-5I43 (ONLINE)

Page: I I8-I30

\section{CAPITAL STRUCTURE DETERMINANTS: EVIDENCE FROM PALESTINE AND EGYPT STOCK EXCHANGES}

\author{
Abdul Razak Abdul Hadi,Shadi Ali Hamad\&TulusSuryanto \\ University of Kuala Lumpur Malaysia,University of Kuala Lumpur Malaysia \\ \&IAIN RadenIntan Lampung Indonesia \\ abdrazak@,unikl.edo.my, hamad_shadi@,yahoo.com\&tulus@,iainradenintan.ac.id
}

\begin{abstract}
This study is driven by the motivation to examine the capital structure determinants for Palestine Stock Exchange (PEX) and Egypt Stock Exchange (EGX). Within the framework of capital structure theories, this study uses Generalized Method of Moments (GMM,1982) as an estimation model employing quarterly panel data analysis during the observed period from 2008 till 20I2. The test results from GMM indicate that all the examined determinants have significant relationship with leverage. It has a negative value with liquidity, non-debt tax shield, profitability, size and growth. The Egyptian firms have some uniqueness in its trend. Current assets, debt ratio and liquidity behave positively with leverage except for growth. The other tested determinants in Egyptian companies are found to be not significant.
\end{abstract}

Keywords : PEX; EGX; GMM Test; Panel Data Analysis; Capital Structure Determinants

\begin{abstract}
Abstrak-Penelitian ini didorong oleh motivasi untuk memeriksa faktor-faktor penentustruktur modal untuk Bursa Efek Palestina (PEX) dan Bursa Efek Mesir (EGX). Dalam kerangka teori struktur modal, penelitian ini menggunakan metode Generalized Moments (GMM, 1982) sebagai model estimasi menggunakan analisis data panel kuartalan selama periode yang diamati dari 2008 sampai 2012. Hasil tes dari GMM menunjukkan bahwa semua factor penentu yang diperiksa memiliki hubungan yang signifikan dengan leverage. Memiliki nilai negatif dengan likuiditas, non-utang pajak perisai, profitabilitas, ukuran dan pertumbuhan. Perusahaan Mesir memiliki beberapa keunikan dalam trend-nya. Aktiva lancar, rasio hutang dan berperilaku likuiditas positif dengan leverage kecuali untuk pertumbuhan. Faktor-faktor penentu diuji di perusahaan Mesir yang ditemukan tidak signifikan.
\end{abstract}

Kata Kunci : PEX; EGX; GMM Test; Analisis Data Panel;

Penentu Struktur Modal

\section{INTRODUCTION}

Several researchers have investigated the determinants of capital structure both internal and external ones, some of which have significant influence while others do not. Yet, they do not have a unified theory of capital structure even after decades of intensive work and this leaves the topic open for further studies and more of country 
customization. Through obtaining the optimal capital structure, a lot of companies can withstand various difficult and risky situations.Arguably, why focusing on Palestine, Jordan and Egypt, and why not be contented with the results and empirical findings of the prior studies that have already been conducted in the context of the developing markets? Alves and Ferreira (2007); and several others argued that the determinants of capital structure are significantly affected by jurisdictional factors like corporate and personal tax system, corporate governance, and laws and regulations of the country; and in that sense, it is very important to study each developing country by its own individually rather than pooling countries together. The Palestinian economy has undergone a lot of ups and downs through the last decades, following the second intifada (2000), the occupation imposed sanctions on GAZA, the siege and the separating walls around the West Bank and yet after a decrease of $8 \%$ in the growth rate of GDP in 2006, a positively opposite trend of growth continues to increase, with $2 \%$ in 2007, 4\% in 2008 and about 9\% in 20II.This growth is reflected in better yearly GDP per capita values: \$ I4I5, $\$ 1502, \$ 1635$ in 2009, 2010, and $201 \mathrm{I}$ respectively. The Palestinian stock market also grew simultaneously in its market capitalization, scoring 2.44 trillion in 20I0, 2.78 in $201 \mathrm{I}$ and 3 trillion in 2012. PEX trades in stocks and until now there is no bonds market.

The firms of the study are listed in emerging stock market, with some features that differ clearly from those working in the developed markets. These markets are characterized with thin trading, inefficiency, weak organization and poor information disclosure. In comparing the percentage of the Arab stock markets capitalization to GDP and turnover ratios in 200I, we found that, generally, the averages of these ratios are $26 \%$ and $6 \%$ respectively, while $33 \%$ and $29 \%$ are the averages for developing countries (Bolbol, A. and Omran, M 2004). This does comply with our case where the Palestinian market ratio is $30.2 \%$ in 2012 , from I 997 to 2005. There are situations that influence the capital structure choice, like economic conditions, where the demand and supply of capital in the marketplace, influence the way capital is raised. The market conditions also have their effect: higher rates of return will increase the cost of capital. The operating conditions, that is, the level of fixed costs is used to operate the business needs. Capital structure is also determined by the financial conditions and higher levels of debt can result in wider variations to earnings due to higher fixed obligations that must be paid. This is referred to as financial risk. Samuel and Frank (2000) studied 
a sample from companies in China. The results of Dimitrios, Nikolaos and Nikolaos (200I) intersect with those of Samuel in that larger firms employ more debt in financing their capital. Furthermore, the researchers found that the Greek companies with high profitability ratios prefer to use less debt than companies with less profit. They stated that firms do follow a target capital structure.Faris (20II) indicated that the listed service companies in the Palestine exchange (PEX) had the highest total debt ratio followed by the industrial companies. Trading and agricultural companies come last. There was no difference between the sectors in the use of debt, and no variance with respect to growth opportunities, size, age, tangibility, and liquidity. By examining the capital structure determinants and their correlation with leverage ratios, the results show that total debt ratio is positively and significantly related to tangible assets. On the contrary, no significant relationship exists between the long-term debt and short-term debt on the one hand and age, growth, liquidity, tangibility, and size on the other.Khaldoun M. and Mohammad F. (2013) tested the determinants of capital structure in the Palestinian market between 2003 and 2007 and they found that listed Palestinian firms have low leverage ratios, its long-term debt is literally non-existent, and that capital structure (firm size and firm profitability) are applicable to the Palestinian case.Faris (20II) selected a sample from the Jordanian banks and found that Size tangibility variables have a positive influence both on capital structure and on growth, while risk and ownership variables have a negative influence on capital structure.Suryanto, T., \& Abdul Hadi, A. R. (20I5) This study is a significant equilibrium relationship between Palestine Stock Exchange and Tel Aviv Stock Exchange but no empirical evidence was found on the presence of dynamic relations between the two stock markets in TASE Index do influence the performance of PEX.Husni and Ali (2007) selected in their study of the Jordanian Industrial Companies with the following explanatory variables: size, tangibility, profitability, long-term debt and shortterm debt. They found a positive relationship between leverage and size, and also between short and long-term debt with tangibility and profitability. Equity is the dominant financing tool, and the internal financing represent $70 \%$ of this equity in the industrial sector. Profitability is negatively correlated with the short-term financing, and generally short-term debt is less likely to be used by profitable and large firms.Huang and Song (2002) found in their study of a panel data of listed companies in China that there is a significant relation between the company's size and its 
debt ratios. Antonion et al. (2008) broadened the analysis of the determinants of capital structure choice and found that the capital structured decisions of firms financing is affected by the surrounding environment, macro-economic conditions and the status of the stock market.S., Gureharan (20I0), in a review of optimal capital structure determinants of ASEAN countries indicated that there is an inverse relationship between leverage ratios as dependent variable and profitability and growth as the independent factors. Non-debt tax shield has significant negative impact on leverage mainly for Malaysia. The size of the company is positively related with leverage for Indonesia and Philippine index link companies. Country effect as an external factor showed that the GDP growth rate is positively related to leverage, and on the contrary, the inflation has a significantly negative effect. Abdul Kader (2005) examined the listed companies in Saudi Arabia and found that the debt ratios are positively related to the growth in total assets, but negatively related to assets structure and liquidity. Dinesh (20I0) in the case of Nepalese listed companies, found that firms are highly levered but with a low long-term debt ratio. Leverage is positively related to the assets structure and size, whereas liquidity, risk, growth, non-debt tax shield are negatively related to leverage.
The theories of capital structure and the signs of the determinants and results correspond with pecking order and trade-off theories. The managers of the Nepalese firms prefer internal financing more than external funding.According to Joy Pathak (2009), factors such as tangibility of assets, growth, firm size, business risk, liquidity, and profitability have significant influences on the leverage structure chosen by firms in the Indian context.

\section{DATA \& METHODOLOGY}

Generalized Method of Moments (GMM) is employed in testing the determinants of capital structure and their relation with leverage (debt/equity ratio). This method provides the panel data with an efficient econometric estimators. GMM is an efficient test and tool that can reduce and ease endogeneity problem. Endogeneity is the correlation between the parameters or variables with the error term. This test controls the endogeneity problem by employing unobservable shocks in the crosssectional component. The research instruments used in this study involve diagnostic tests for GMM validity which are tests of the non- existence of serial correlation of the error terms using the first and second order serial correlation, test for exogeneity of instruments that ensures the consistency of estimates using the 
Sargan tests. This test is also employed to find out the relation between capital structure determinants and debt equity ratio $(\mathrm{D} / \mathrm{E})$. The research frame work of the GMM test is shown in Figure I below. It is developed to test the determinants of capital structure. To depend on the GMM results, different diagnostic tests are conducted. Sargan test is employed to measure the exogeneity and validity of instruments, while the serial correlation is examined by Autocorrelation test.Generalized Method of Moments (GMM) provides the panel data with an efficient econometric estimator. It considers both dimensions of time-series and cross-sectional (Hsiao, I985). GMM is an efficient test and tool that can reduce and ease endogeneity (Arellano and Bond, I99I; Blundell and Bond, 1998). The data are gathered on country and sector level for the listed companies in these three markets. The period of study is from 2008 until 2012. Our sample includes 63 companies without any negative, missing or zero values. In evaluating the capital structure effect, the debt equity ratio is employed as a dependent variable and the current ratio, assets structure, non-debt tax shield, profitability, growth and size as the independent variables. In testing that relations, a Pooled OLS and GMM are deployed.

\section{EMPIRICAL FINDINGS}

The Sargan test is performed to explore the over identifying restrictions. This test is measured by Chi- squared $\rho$ value. To test the validity of the used instruments, the following hypothesis must be tested:

$\mathrm{H}_{0}$ : The instruments used in this model are valid.

$\mathrm{H}_{\mathrm{r}}$ : The instruments used in this model are not valid.

A strong evidence of the validity of the model is achieved and the Chi square result is not significant. The Sargan test measures the validity of the instruments used in the estimation. This test is used to find out if these instruments are correlated with the error term (absence of unobserved firm-specific effect). As shown in Table $I$, the results of the $p$ value of the Sargan test for the total sample is 0.46. This non-significant $\rho$ value emphasizes the overall validity of the instruments and the tested determinants of capital structure. The serial correlations AR (M) determine the absence or existence of first and second order serial correlations. The results in The inexistence of serial correlation, with a value of 0.98. First and Second Order Autocorrelation tests of residuals are employed to test the null hypothesis of no serial correlation.

$\mathrm{H}_{0}$ : There is no serial correlation.

$\mathrm{H}_{\mathrm{r}}$ : Serial correlation is found.

No serial correlation is found, and the null hypothesis is accepted. 


\section{Capital Structure Determinants:}

Evidence From Palestine And Egypt Stock Exchanges

(Abdul Razak Abdul Hadi,ShadiAli Hamad\& Tulus Suryanto)

This result indicates that there is no significant unobserved firm specific effect.According to the results in Table 2 , the $\rho$ value of lagged dependent variable (debt to equity ratio) with the other independent variables is significant in most of the cases (0.000I). The current ratio which is current assets over current liabilities is negatively related with leverage, and the more liquidity the firm's assets, the less need for debt. Firms that have more liquidity employ less debt in their capital structure. This result supports the Pecking Order Theory, where firms prefer internal cash flow to external sources. This finding supports the studies by Ozkan(200I). The size of the companies (as proxied by Ln sales) is negatively related with leverage. Titman and Wessels (I988) suggested natural logarithm of sales as indicator of size. In this study, as suggested by Titman and Wessels (1988), the net sales have been adopted. The impact of size on leverage ratios shows significantly results. This output is not consistent with the Trade-Off Theory, where the firm uses more debt if its cost is low. This evidence was emphasized by Rajan and Zingales (I995). So, while small firms which face higher bankruptcy risks and costs try to reduce their debt, large firms, which have an easy access to creditors, do not refrain from using debt in leverage (Bennett and Donnelly, I993; Antoniou et al., 2008; Flannery and Rangan, 2006). The tested companies did not comply with these positive debt and size relations.It is also named the tangibility of assets (Titman and Wessels, 1988). Fixed assets are thus not highly considered by creditors in providing loans. A possible explanation for this is that collateral value of a fixed asset is not easily sold in Egypt, Palestine and Jordan, in case a firm becomes bankrupt. The liquidation cost of the firm's tangible assets, being high, leads banks to refrain from using this source of collateral, without adjusting the cost of loans to firm accordingly. According to the Pecking Order Theory, a firm is more sensitive to information asymmetries if it has few tangible assets. Such a company prefers debt finance instead of equity in financing external capital requirement (Harris and Raviv, I99I). Thus, one expects a positive relation between tangible assets and leverage. Our results contradict that of Titman and Wessels (1988), Rajan and Zingalles (1995). The ratio of annual depreciation to total assets is taken as proxy for non-debt tax shield. Therefore, Non-debt tax shield = annual depreciation/ total assets. The results indicate that non-debt tax shields had negative relation with debt, emphasizing the assumptions of the trade-off theory. In a study by DeAngelo and Masulis (1980), the authors consider investment tax credits and tax deductions for depreciation as substitutes for the tax benefits arising from debt financing. Hence, less debt is included in the capital structure of firms that have a large non-debt tax shields compared to their expected cash flow. Hence, one cannot defend the claim of the existence of a substitution effect of non-debt tax shields, as mentioned in the study of Wijst and Thurik (1993). The ratio of earnings before interest, tax and depreciation, EBITDA, to total assets is considered as proxy to profitability (Titman and Wessels, 1988; Ozkan, 200I; and 
Gaud et al., 2005). Therefore, Profitability $(\mathrm{PRO})=$ EBITDA / total assets. It is obvious from the results in Table 6.I0 that profitable companies lend less. This negative result is found to hold for all the tested sectors and countries. This is exactly what the Pecking Order Theory predicts, since firms with high profitability use less debt than retained earnings in their capital structure. The tested companies prefer internal funds rather than debt. These results are consistent with that of Booth et al., (200I); and Rajan and Zingales, (1995).Rapid growth of a firm often needs expanding its fixed assets, thus, increasing the need for funds, and retaining of earnings. The Trade-Off Theory expects issuance of more debt by the firm for maintaining the suitable debt ratio. This positive relationship between growth and debt ratio is also supported by the Pecking Order Theory. This positive relationship did not match with the overall sample. It is not consistent with Titman and Wessels (1988) and Rajan and Zingales (1995), who found no relationship between leverage and growth.

The proxy of firm's size is calculated by finding the logarithm of sales. Titman and Wessels (I988) suggested natural logarithm of sales as indicator of size. In this study, as suggested by Titman and Wessels (I988) the net sales have been taken. The results show significantly negative impact of size on leverage. This negative relation is not consistent with the Trade-Off Theory, as the firm uses debt if its cost is low. So, while small firms which face higher bankruptcy risks costs try to reduce their debt, large firms, which have an easy access to creditors, do not refrain from using debt in leverage (Bennett and Donnelly, 1993; Antoniou et al., 2008; Flannery and Rangan, 2006). Larger companies usually easily diversify their financing and investments and fail less often. The main determinant of the leverage ratio is the cost of liquidation and financial distress of these large firms. The liquidation process in the tested countries is very long and costly. Collateral assets will mitigate and limit the problem of the cost and length of liquidation procedures. Debt ratio is the division of total debt over total assets. Significant positive relationship is found with debt equity ratio. The more debt to assets, the more the debt to equity is.Employing Generalized Method of Moments (GMM) Analysis for Egyptian Stock Market, a GMM model is developed to test the dynamic relationship between the tested variables. The determinants of capital structure of the Egyptian companies are tested in this section. To estimate the several specification of the dynamic model and in order to test the applicability of GMM on the Egyptian firms, we run the following test statistics:

The Sargan test is performed to explore the over identifying restrictions. This test is measured by Chi- squared $\rho$ value. To test the 
validity of the used instruments, the following hypothesis must be tested:

$\mathrm{H}_{0}$ : The instruments used in this model are valid.

$\mathrm{H}_{1}$ : The instruments used in this model are not valid.

The Sargan test measures the validity of the instruments used in the estimation. The results of the $p$ value of the Sargan test for the total sample is 0.99 . This non-significant $P$ value emphasizes the overall validity of the instruments and the tested determinants of capital structure. The serial correlations AR $(\mathrm{m})$ determine the absence or existence of first and second order serial correlations. The results of $A R$ indicate the inexistence of serial correlation, with a value of 0.97.First and second order autocorrelation tests of residuals are employed to test the null hypothesis of no serial correlation.

$\mathrm{H}_{0}$ : There is no serial correlation.

$\mathrm{H}_{1}$ : Serial correlation is found.

Correlation is found, and the null hypothesis is accepted. This result indicates that there is no significant unobserved firm specific effect. According to the results The $\rho$ value of lagged dependent variable (debt to equity ratio) with the other independent variables is significant especially with liquidity, non-debt tax shield, assets structure, growth and debt ratio. This kind of results implies that these determinants can interpret the relation, and to confirm their effect on capital structure. To highlight these important results, see the following discussion: After testing the liquidity relation with leverage for the stock market of Egypt, a significant negative relationship is found with debt. The tested leverage ratio is debt over equity and the estimated co-efficient were significant at a $5 \%$ level. The ratio of current assets to current liabilities has been chosen as proxy for liquidity.

Firms that have more liquidity employ less debt in their capital structure. This result supports the Pecking Order Theory, where firms prefer internal cash flow to external sources. The results of the study do not support the finding of Ozkan (200I).In a study by DeAngelo and Masulis (I980), the authors considered investment tax credits and tax deductions for depreciation as substitutes for the tax benefits arising from debt financing. Hence, less debt is included in the capital structure of firms that have a large non-debt tax shields compared to their expected cash flow. The ratio of annual depreciation to total assets is taken as proxy for non-debt tax shield. Therefore, Non-debt tax shield = Annual depreciation/ total assets. The proxy for non-debt tax shield shows significant negative results for the overall sample. Hence, the output does not emphasize the claim of the existence of a substitution effect of non-debt tax shield, as mentioned in the study of Wijst and Thurik (I993).

Leverage and capital structure of assets is sometimes named Collateral Value of Assets. Most Capital Structure Theories argue that the type of assets owned by a firm affects its capital structure choice. Firms with assets that can be used as collateral may be expected to issue more debt, while firms with less collateral assets may choose higher debt levels to limit their managers' consumption of prerequisites. Two indicators are generally used for the collateral value attribute: (a) The ratio of intangible assets to total assets, which is negatively related to that attribute and (b) the ratio of inventory and gross plant and equipment to total assets, which is positively related to it. 
Following the results of Titman and Wessels (1988) and following Gaud et al., (2005), the second indicator was adopted in our study. Therefore, Collateral Assets Structure (AS) = (Fixed Assets + Inventories) / Total assets. It is reasonable to assert that tangible assets reduce the loss that financiers of the firms may face in case of its default, and consequently of the positive relationship between leverage and the proportion of tangible assets which is predicted by the Trade-Off Theory, and expected to be applied. This positive relation is found in the GMM results. A case which was found to hold for some Italian firms, Titman and Wessels (I988), Gaud et al., (2005), Rajan and Zingales (I995). The proxy of firm's size is calculated by finding the logarithm of sales. Titman and Wessels (I988) suggested natural logarithm of sales as indicator of size. In this study, as suggested by Titman and Wessels (I988), the net sales is adopted. The results show no impact of size on all the leverage ratios. This is not consistent with the TradeOff Theory, as the firm uses debt if its cost is low. So, while small firms which face higher bankruptcy risks costs try to reduce their debt, large firms, which have an easy access to creditors, do not refrain from using debt in leverage (Bennett and Donnelly, I993; Antoniou et al., 2008; Flannery and Rangan, 2006).

Rapid growth of a firm often needs expanding its fixed assets, thus, increasing the need for funds, and retaining of earnings. The Trade-Off Theory expects issuance of more debt by the firm for maintaining the suitable debt ratio. This positive relationship between growth and debt ratio is also supported by the Pecking Order Theory. This positive relationship is significant for the manufacturing firms.
This result is not consistent with Titman and Wessels (I988) who found no relationship between leverage and growth.Debt ratio is the division of total debt over total assets. Significant positive relationship is found with debt equity ratio. The more debt to assets, the more the debt to equity is.Employing the Generalized Method of Moments (GMM) Analysis for Manufacturing Companies, a GMM model is developed to test the dynamic relationship between the tested variables. The determinants of capital structure of the manufacturing companies are tested in this section. The Sargan test is performed to explore the over identifying restrictions. This test is measured by Chi- squared $\rho$ value. To test the validity of the used instruments, the following hypothesis must be tested:

$\mathrm{H}_{0}$ : The instruments used in this model are valid.

$\mathrm{H}_{\mathrm{r}}$ : The instruments used in this model are not valid.

The analyze the tested determinants of capital structure of the manufacturing companies, the two-step GMM test is implemented. The Sargan test measures the validity of the instruments used in the estimation. The results of the $p$ value of the Sargan test for the total sample is 0.99. This non-significant $\mathrm{P}$ value emphasizes the overall validity of the instruments and the tested determinants of capital structure. The serial correlations AR ( $\mathrm{m}$ ) determine the absence or existence of first and second order serial correlations. The results of AR indicate the inexistence of serial correlation, with a value of 0.97 . First and second order autocorrelation tests of residuals are employed to test the null hypothesis of no serial correlation. $\mathrm{H}_{0}$ : There is no serial correlation. $\mathrm{H}_{1}$ : Serial correlation is found. 
No serial correlation is found, and the null hypothesis is accepted. This result indicates that there is no significant unobserved firm specific effect.

According to the results $\rho$ value of lagged dependent variable (debt to equity ratio) with the other independent variables is significant just with profitability with a negative coefficient value. This negative result emphasis the results of many researchers who found that, firms with high profitability use less debt than retained earnings in their capital structure. See also, in this regard, Booth et al., (200I); and Rajan and Zingales, (1995). Debt ratio is the division of total debt over total assets. Significant positive relationship is found with debt equity ratio. The more debt to assets, the more the debt to equity is.

\section{CONCLUSION}

The analysis employed GMM as a robust econometric test on the balanced panel dataset, for PEX, ASE and EGX. A model was developed in this study for testing the determinants of capital structure. Important results are visible from the overall balanced sample. The balanced panel dataset analysis revealed that the level of external financing exceeds $41 \%$ for the manufacturing and property companies, and is just $33 \%$ for the service firms. Manufacturing and service companies' long-term financing does not exceed $10 \%$ and dramatically less is the property sector with just $6 \%$. Testing the seven independent determinants of capital structure and its impact on leverage ratios, the following important results are found: Liquidity shows a significant negative relationship with the leverage ratios. Firms that have more liquidity employ less debt in their capital structure, thus supporting the Pecking Order Theory, where firms prefer internal cash flow to external sources of finance. Dinesh Prasad (2010), found that liquidity, risk, growth, non-debt tax shield are negatively related to leverage. This negative result, is totally different for the Egyptian companies that has positive results. The manufacturing sector coefficients of liquidity and debt equity ratio are not statistically significant. Faris M. (20II) reveals in his study that the total debt ratio is positively and significantly related to tangibility, on the contrary, no significant relationship exists between the leverage and growth, liquidity, size and assets structure. The study of HusniKhrawish (2007) had some similar results as of that of the Egyptian firms regarding tangibility and assets structure. Testing the nondebt tax shield, the proxy for non-debt tax shields, shows negative and significant results. Therefore, there is a lack of empirical support on the presence of a substitution effect of non-debt tax shields. From the Pecking Order Theory perspective, a positive trend between tangible assets and leverage is expected. Trade-Off Theory predicts a positive relationship between leverage and the proportion of tangible assets. This positive relation is not found in all the tested groups, all the sectors sample, Egypt companies, and manufacturing firms.

It is obvious from the results that profitable companies borrow less, this result is also confirmed by Zahran M (2010). This negative result was found to hold for all sample and manufacturing companies, but not for the Egyptian firms. This is consistent with the Pecking Order Theory, since firms with high profitability use more retained earnings and less debt in their capital structure. 
The results of the total sample show a significantly negative impact of size on leverage but the Egyptian firm's results are consistent and supports the TradeOff Theory, where the firm employs more debt as the cost of debt is low, and large firms have better access to credit markets because they face lower bankruptcy costs. Small firms reduce their debt because they are more exposed to bankruptcy costs.

According to the Trade-Off Theory, the retained earnings of high growth firms increase and they issue more debt to maintain the target debt ratio. Thus, a positive relationship between debt ratio and growth is expected according to this argument. The same relationship is supported by Pecking Order Theory too. This positive relationship is not supported in our sample and the tested relation in most of the cases has a negative coefficient or no effect as the manufacturing companies.

Faris M (20II), investigated the determinants of capital structure of the Palestinian listed companies and found that total debt is positively and significantly related to assets structure, and no relation with growth, liquidity, size.

\section{REFERENCES}

Abdulkader M.A. Abdullah (2005), "Capital Structure and Debt Maturity: Evidence from Listed Companies in Saudi Arabia" Journal of Business and Economics, I I, I5-33.

AkthamMaghyereh, (2005), "The Capital Structure Choice and Financial Market Liberalization: A Panel Data Analysis and GMM Estimation in Jordan" Journal of Economics and Management I3, no.I.

Ali, S. and Iman , m. (2013)" The Determinant of capital Structure: Evidence from an Emerging Market”, Journal of Asia Pacific Business Innovation \& Technology Management, 003.

Alves, P. Ferreira, and Miguel, A. (2007), "Capital Structure and Law around the World" (march). I4th Annual Conference of the Multinational Finance Society.

Antoniou, A., Guney, Y., and Paudyal, K. (2008), "The Determinants of Capital Structure: Capital Market-Oriented versus Bank-Oriented Institutions" Journal of Financial and Quantitative Analysis, 43 (I), 59-92.

Ang, J.S., Chua, J.H., \&McConnel, J.J. (I982), "The Administrative Costs of Corporate Bankruptcy: A Note", Journal of Finance, Vol. 37, No. I, 2I9226.

Arellano, Manuel, and Stephen Bond. (I99I) "Some Tests of Specification for Panel Data: Monte Carlo Evidence and an Application to Employment Equations." Review of Economic Studies 58, no. 2:277-97.

Azman,S., Ahmad Z. and Siong H., (2010) "Foreign direct investment, economic freedom and economic growth: International evidence" Journal Economic Modelling, 27 (2010) I079-I089.

Bennett, M., and Donnelly, R. (I993), "The Determinants of Capital Structure: Some UK Evidence” The British Accounting Review, 25 (I), 43-59.

Blundell, R \& Bond, S (I998), 'Initial conditions and moment restrictions in dynamic panel data models', Journal of Econometrics, vol. 87, no. I, pp. I I5-43. 
Bolbol, A., and Omran, M. (2004), "Arab Stock Markets and Capital Investment" Arab Monetary Fund, UAE.

Cassar, and Holmes. (2003), "Capital structure and financing of SMEs. Contemporary Approach" University of Pretoria. p I29.

DeAngelo, Harry and Masulis, Ronald W. (1980), "Optimal Capital Structure Under Corporate and Personal Taxation" Journal of Financial Economics, $8(\mathrm{I}), 3-27$.

Dinesh Prasad Gajurel (2010), "Capital Structure Management in Nepalese Enterprises"Master's Degree Thesis, Kathmandu: Faculty of Management, Tribhuvan University.

Easterbrook, F. (1984), "Two-Agency Cost Explanations of Dividends" American Economic Review, 74, 650-659.

Faris M. (20II), "The Determinants Of Capital Structure Of Palestine-Listed Companies” Journal of Risk Finance. 226.

Fazzari S.M., Hubbard, R.G., Petersen. (I988), "Financing Constraints and Corporate Investment" Brookings Papers on Economic Activity, I988 (I), I4I-I95.

Flannery, M.J., and Rangan K.P., (2006), "Partial Adjustment toward Target Capital Structures" Journal of Financial Economics. 79 (3), 469-506.

Gaud, P., E. Jani, M. Hoesli, and A. Bender, (2005), "The Capital Structure of Swiss Companies: An Empirical Analysis using Dynamic Panel Data" European Financial Management, Vol. II, pp. 51-69.

Harris, M., and Raviv, A. (I99I), "The Theory of Capital Structure" The Journal of Finance. 46, 297-355.

Hsiao, C (1985), 'Benefits and limitations of panel data', Econometrics Review, vol. 46, no. 4, pp. I25I-7I.

Huang, S., and Song, F. (2002), "The Determinants of Capital Structure: Evidence from China" Working paper, The University of Hong Kong, pp: 2-7.

HusniKh., and Ali H. (2007), "The Determinants of the Capital Structure: Evidence from Jordanian Industrial Companies" Econ. \& Adm., Vol. 24 No. I, pp: I73-196.

Jalilvand, A \& Harris, RS I984, 'Corporate behavior in adjusting to capital structure and dividend targets: An econometric study', Journal of Finance, vol. 39, no. I,pp. I27-45.

James H. Scott, Jr. (I977)” Bankruptcy, Secured Debt, and Optimal Capital. Structure" The Journal of Finance Vol. 32, No. I, Mar., pp. I-I9

Jensen, M. (1986), "Agency Cost of Free Cash Flows, Corporate Finance and Takeovers" American Economic Review, Vol. 76, pp. 323-339.

Joy Pathak. (2009), "What Determines Capital Structure of Listed Firms in India?" Baruch College, City University Of New York, 55 Lexington Ave New York, I00IO, United States June: 399-423.

Kadapakkam, P., Kumar, P.C., and Riddick, L.A. (1998), "The Impact of Cash Flows and Firm Size on Investment: The International Evidence" Journal of Banking and Finance. 22(2), 293-320

Khaldoun M. and Mohammad F. (2013)," The Determinants of Capital Structure: Palestinian Case (2003 - 2007) Interdisciplinary Journal of Contemporary Research in Business. 4(I2). 
Modigliani, F.F., and M. H. Miller. (I963), "Corporation Income Taxes and the Cost of Capital: A Correction" A Mercian E economics review (June).

Modigliani, F.F., and M.H. Miller, (I958), "The Cost of Capital, Corporation Finance, and the Theory of Investment" American Economic Review (June).

Myers, Stewart C., Majluf, Nicholas S. (I984), "Corporate financing and investment decisions when firms have information that investors do not have" Journal of Financial Economics. I3(2), I87-22I.

Myers, Stewart."Determinants of Corporate Borrowing. (I977)" Journal of Financial Economics 5, no. 2: 147-75.

Ozkan, A. (200I), "Determinants of Capital Structure and Adjustment to Long Run Target: Evidence from UK Company Panel Data” Journal of Business Finance and Accounting. 28, I75-I98.

Rajan, and Luigi Z. (I995), "What Do We Know about Capital Structure? Some Evidence from International Data” Journal of Finance. 50 (5), I42I-I460.

S. Gureharan, (20I0), "A Review of Optimal Capital Structure Determinant of Selected ASEAN Countries” Accounting \& Audit Department, University of Malaya, Malaysia 2010.

Samuel, G. (2000), "The Determinants of Capital Structure: Evidence from China" School of Economics and Finance and Centre for China Financial Research (CCFR).

Sheridan, T., and Roberto, W. (I988), "The Determinants of Capital Structure Choice" Journal of Finance. 43(I), I-I9.

Suryanto, T., \& Abdul Hadi, A. R. (2015). Capital market integration: Palestine and Israeli experience. Al-Iqtishad: Journal of Islamic Economics, 7(2), I97-206.

Titman, S., and R. Wessels, (I988), "The Determinants of Capital Structure Choice” Journal of Finance. 43, I-I9.

Wijst Van der, N., and Thurik, R. (I993), "Determinants of Small Firm Debt Ratios: An Analysis of Retail Panel Data” Small Business Economics, vol. 5, no. I, pp. 55-65. 